Making the Mexican Diabetic 
This page intentionally left blank 


\section{Making the Mexican Diabetic}

Race, Science, and the Genetics of Inequality

\section{Michael J. Montoya}

甲 
University of California Press, one of the most distinguished university presses in the United States, enriches lives around the world by advancing scholarship in the humanities, social sciences, and natural sciences. Its activities are supported by the UC Press Foundation and by philanthropic contributions from individuals and institutions. For more information, visit www.ucpress.edu.

University of California Press

Berkeley and Los Angeles, California

University of California Press, Ltd.

London, England

(C) 20 I I by The Regents of the University of California

Library of Congress Cataloging-in-Publication Data

\section{Montoya, Michael J. I965-}

Making the Mexican diabetic : race, science, and the genetics of inequality / Michael Montoya.

p. $\mathrm{cm}$.

Includes bibliographical references and index.

ISBN 978-0-520-26730-5 (hardcover : alk. paper)

ISBN 978-0-520-2673 I-2 (pbk. : alk. paper)

I. Non-insulin-dependent diabetes-Mexico-

Genetic aspects. 2. Mexican Americans-Health and hygiene. I. Title.

[DNLM: I. Diabetes Mellitus-ethnologyMexico. 2. Diabetes Mellitus_ethnology_United States. 3. Genetic Research-Mexico. 4. Genetic Research-United States. 5. Indians, North American-ethnology-Mexico. 6. Indians, North American-ethnology-United States. 7. Mexican Americans-ethnology-Mexico. 8. Mexican Americans-ethnology-United States. 9. Risk Factors-Mexico. Io. Risk Factors-United States. II. Socioeconomic Factors-Mexico.

I2. Socioeconomic Factors-United States. WK 8Io] RA645.D5M66 20II 362.I96'46200896872073-dc22

2010038017

Manufactured in the United States of America

I9 I8 I7 I6 I5 I4 I3 I2 II IO

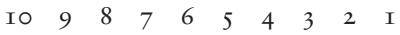

This book is printed on Cascades Enviro roo, a I०० \% post consumer waste, recycled, de-inked fiber. FSC recycled certified and processed chlorine free. It is acid free, Ecologo certified, and manufactured by BioGas energy. 
For Johanna, Zoe, Eliah, and Sidra for accompanying me on this journey. I delight in the prospects of accompanying you on yours. 
This page intentionally left blank 